\title{
A COMPARATIVE STUDY BETWEEN ORGANIC AND CONVENTIONAL TABLE EGGS
}

\author{
YASSER, S. WAFY \\ Fellow, Assiut University Hospitals

Assiut University web-site: $\underline{\text { www.aun.edu.eg }}$

\section{ABSTRACT}

Received at: 31/3/2015

Accepted: 19/4/2015
A total of 300 random samples of organic and conventional eggs (150 of each) were obtained from supermarkets in Assiut city, Egypt from July to December, 2014. Thirty batches of eggs from each type were examined. Each batch comprised 5 eggs (one from each for bacteriological examination and detection of antibiotic residues). In organic eggs, all samples [30] (100\%) were contaminated with bacteria and the total bacterial counts / shell and $\mathrm{ml}$ of albumen and yolk egg samples ranged from $3.6 \times 10^{2}, 1.5 \times 10^{1}$ and $>10^{1}$ to $2.7 \times 10^{4}, 4.3 \times 10^{2}$ and $4.8 \times$ $10^{1}$ with average counts of $6.4 \times 10^{3}, 6.6 \times 10^{1}$ and $2.8 \times 10^{1} \mathrm{cfu}$, respectively. The highest frequency distribution was $16(53.33 \%), 21(70 \%)$ and $25(83.33 \%)$ lied within the ranges of $10^{3}-, 10^{1}-$ and $10^{1}-\mathrm{cfu}$ in shell and $\mathrm{ml}$ of albumen and yolk of organic egg samples, respectively. In conventional eggs, all samples [30] (100\%) were contaminated with bacteria and total bacterial counts / shell and ml of albumen and yolk samples ranged from $4.7 \times 10^{1},, 1.6 \times 10^{1}$ and $1.1 \times 10^{1}$ to $2.2 \times 10^{3}, 2.8 \times 10^{1}$ and $1.9 \times 10^{1}$ with average counts of $7.4 \times 10^{2}, 1.9 \times$ $10^{1}$ and $1.5 \times 10^{1} \mathrm{cfu}$, respectively. The highest frequency distribution was $15(50 \%)$, $30(100 \%)$ and $30(100 \%)$ lied within the ranges of $10^{2}, 10^{1}$ and $10^{1}$ cfu / shell and $\mathrm{ml}$ of albumen and yolk of conventional egg samples, respectively. All organic egg samples were free from antibiotics, but only 3 samples (10\%) of conventional eggs were contaminated by antibiotics. The health importance of organic and conventional eggs, methods of contamination by antibiotics and methods of control are discussed.

Key words: Organic eggs, conventional eggs, total bacterial counts, antibiotics

\section{INTRODUCTION}

Organic eggs, one of the most important food that recently appear in markets and raising the demand to it by the consumers from day to another has been noticed. It have shifted from being consumed by small scale of consumers to being consumed by large scale of consumers who perceive that organic food provides environmental and health benefits due to the limited amount of chemical residues and veterinary drugs specially growth promoters and antibiotics which routinely and periodically used in poultry farms producing table eggs to prevent and treat many diseases. Antibiotics deposits in poultry meat and eggs and transmitted to the consumers causing many development of antibiotic resistant bacteria in human being (Sahin et al., 2002).

Consumers choose to buy organic food because they think that this food is safer and that organic production practices are better for the environment and animal welfare (Sylvander, 1999). Organic egg may be more attractive to consumers than some other organic food because the fact that table eggs constitute an important part of the human diet in many countries and are traded internationally (Corry, 2007) and it considered one of the most important source of high protein and considered as a good source of high quality unsaturated fatty acids, vitamins and minerals. So, large scale of consumers depend on it in their diet at all stage of life from baby stage till old age which act as excellent food due to easy digestibility, low caloric value, availability, easy preparation and moderate coast (Bahout, 1991) and, thus are willing to pay a higher price (Onozaka et al., 2006) reach to 70 percent due to high bird mortality in organic systems stems from a number of factors, including predators and disease (Hermansen et al., 2004).

Organic poultry cannot be given growth-producing hormones (which are prohibited in conventional 
systems as well) or antibiotics (USDA, AMS., 2000 ). In addition to that products must be contain organic ingredients and are based on the percentage of organic ingredients in a product consist of at least 95percent organically produced ingredients.

The national organic standards require that organic growers and handlers (including food processors, manufacturers, and some distributors) and address the methods, practices, and substances used in producing and handling crops, livestock, and processed agricultural products. So, a great deal of efforts have been made to produce high quality organic eggs which free from high load of pathogenic microorganisms and any harmful pollution specially growth hormones and antibiotics. So, this work was planned to compare between organic and conventional table eggs quality.

\section{MATERIALS and METHODS}

\section{Collection of samples:}

A total of 300 random samples of organic and conventional eggs (150 of each) were obtained from supermarkets in Assiut city, Egypt from July to December, 2014. Thirty batches of eggs from each type were examined. Each batch comprised of 5 eggs (one from each for bacteriological examination and detection of antibiotic residues). The samples were collected in clean, dry and sterile plastic bags and carried to the laboratory with a minimum of delay where they were examined.

\section{Preparation of samples:}

1-Egg shells (Moats, 1980):

Egg shells was washed by a surface rinse by immersed each egg in $100 \mathrm{ml}$ of $0.1 \%$ sterile peptone water in a jar and shaken for 15 minute in mechanical rotary shaker. The obtained rinse solution from the 5 eggs of each group was combined.

\section{2-Egg contents (Spek, 1976):}

The egg was prepared for evacuation its content by washed each egg with warm water $\left(32^{\circ} \mathrm{C}\right)$ using a brush and soap, the egg was drained and immersed in $70 \%$ alcohol for $10 \mathrm{~min}$. then removed from alcohol and flamed then alcohol was made in a the blunt end of the egg by using sterile scalpel then the albumen of each samples group were removed aseptically in sterile mixer and homogenize each samples group with each other then removed aseptically yolk as albumen.

3-Preparation of serial dilutions (APHA, 1992): Ten-fold serial dilutions up to $\mathbf{1 0}^{\mathbf{6}}$ were aseptically prepared from the rinse solution and homogenous egg contents using 0.1 sterile peptone water.

4-Bacteriological examination: Total bacterial count determined according to FDA (2001).

5- Detection of antibiotic residues (Shahid et al., 2007): The antimicrobial screening of egg was carried out using disc diffusion method where Bacillus subtlis was used as the test organism. An 18 hours culture of the test organism in $10 \mathrm{ml}$ nutrient broth was used to inoculate Mueller Hinton agar plates then sterile filter paper disc $0.6 \mathrm{~cm}$ in diameter was soaked in homogenized egg yolk and and placed gently on Mueller Hinton agar plate which inculcated with a test organism and incubated at $37^{\circ} \mathrm{C}$ for $27 \mathrm{~h}$ after which the plates were viewed for the presence of zone of inhibition of test organisms around the test and control discs. The difference between the diameter of zone of inhibition and that of the disc were calculated. The disc with a difference of $1 \mathrm{~mm}$ or more considered positive for presence of antibiotic.

\section{RESULTS}

Table 1: Statistical analytical results of total bacterial counts / shell and $\mathrm{ml}$ of albumen and yolk of organic egg samples.

\begin{tabular}{ccccccc}
\hline & \multirow{2}{*}{ Type of samples } & $\begin{array}{c}\text { No. of exam. } \\
\text { samples }\end{array}$ & $\begin{array}{c}\text { No. of +ve } \\
\text { samples }\end{array}$ & $\begin{array}{c}\text { \% of +ve } \\
\text { samples }\end{array}$ & & \multicolumn{2}{c}{ Counts ( cfu) $/ \mathrm{ml}$} & \\
\cline { 5 - 7 } & & & & Min. & Max. & Average \\
\hline Egg shell & 30 & 30 & 100 & $3.6 \times 10^{2}$ & $2.7 \times 10^{4}$ & $6.4 \times 10^{3}$ \\
\hline Egg albumen & 30 & 30 & 100 & $1.5 \times 10^{1}$ & $4.3 \times 10^{2}$ & $6.6 \times 10^{1}$ \\
\hline Egg yolk & 30 & 30 & 100 & $>10^{1}$ & $4.8 \times 10^{1}$ & $2.8 \times 10^{1}$ \\
\hline
\end{tabular}


$\underline{\text { Assiut Vet. Med. J. Vol. } 61 \text { No. } 145 \text { April } 2015}$

Table 2: Frequency distribution of the examined shell, albumen and yolk of organic egg samples based on their total bacterial counts (cfu) / shell and ml.

\begin{tabular}{ccccccc}
\hline & \multicolumn{2}{c}{ shell } & \multicolumn{2}{c}{ Albumen } & \multicolumn{2}{c}{ yolk } \\
\hline Intervals /ml & $\begin{array}{c}\text { No. of +ve } \\
\text { samples /30 }\end{array}$ & $\begin{array}{c}\text { \% of +ve } \\
\text { samples }\end{array}$ & $\begin{array}{c}\text { No. of +ve } \\
\text { samples /30 }\end{array}$ & $\begin{array}{c}\text { \% of +ve } \\
\text { samples }\end{array}$ & $\begin{array}{c}\text { No. of +ve } \\
\text { samples /30 }\end{array}$ & $\begin{array}{c}\text { \% of +ve } \\
\text { samples }\end{array}$ \\
\hline$>10^{1}{ }_{-}$ & - & - & - & - & 5 & 16.66 \\
\hline $10^{1}{ }_{-}$ & - & - & 21 & 70 & 25 & 83.33 \\
\hline $10^{2}-$ & 10 & 33.33 & 9 & 30 & - & - \\
\hline $10^{3}$ & 16 & 53.33 & - & - & - & - \\
\hline $10^{4}$ & 4 & 13.3 & - & - & - & - \\
\hline Total & 30 & 100 & 30 & 100 & 30 & 100 \\
\hline
\end{tabular}

Table 3: Statistical analytical results of total bacterial counts / shell and $\mathrm{ml}$ of albumen and yolk of conventional egg samples.

\begin{tabular}{|c|c|c|c|c|c|c|}
\hline \multirow[t]{2}{*}{ Type of samples } & \multirow{2}{*}{$\begin{array}{l}\text { No. of exam. } \\
\text { samples }\end{array}$} & \multirow{2}{*}{$\begin{array}{l}\text { No. of +ve } \\
\text { samples }\end{array}$} & \multirow{2}{*}{$\begin{array}{l}\% \text { of +ve } \\
\text { samples }\end{array}$} & \multicolumn{2}{|c|}{ Counts (cfu) / ml } & \multirow[b]{2}{*}{ Average } \\
\hline & & & & Min. & Max. & \\
\hline Egg shell & 30 & 30 & 100 & $4.7 \times 10^{1}$ & $2.2 \times 10^{3}$ & $7.4 \times 10^{2}$ \\
\hline Egg albumen & 30 & 30 & 100 & $1.6 \times 10^{1}$ & $2.8 \times 10^{1}$ & $1.9 \times 10^{1}$ \\
\hline Egg yolk & 30 & 30 & 100 & $1.1 \times 10^{1}$ & $1.9 \times 10^{1}$ & $1.5 \times 10^{1}$ \\
\hline
\end{tabular}

Table 4: Frequency distribution of the examined shell, albumen and yolk of conventionally egg samples based on their total bacterial counts (cfu) / shell and ml.

\begin{tabular}{ccccccc}
\hline & \multicolumn{2}{c}{ shell } & \multicolumn{2}{c}{ Albumen } & \multicolumn{2}{c}{ yolk } \\
\hline Intervals /ml & $\begin{array}{c}\text { No.of +ve } \\
\text { samples /30 }\end{array}$ & $\begin{array}{c}\text { \% of +ve } \\
\text { samples }\end{array}$ & $\begin{array}{c}\text { No.of +ve } \\
\text { samples /30 }\end{array}$ & $\begin{array}{c}\text { \% of +ve } \\
\text { samples }\end{array}$ & $\begin{array}{c}\text { No.of +ve } \\
\text { samples /30 }\end{array}$ & $\begin{array}{c}\text { \% of +ve } \\
\text { samples }\end{array}$ \\
\hline $10_{-}^{1}$ & 6 & 20 & 30 & 100 & 30 & 100 \\
\hline $10_{-}^{2}$ & 15 & 50 & - & - & - & - \\
\hline $10_{-}^{3}$ & 9 & 30 & - & - & 30 & 100 \\
\hline total & 30 & 100 & 30 & 100 & - \\
\hline
\end{tabular}

Table 5: Incidence of antibiotic residues in the examined organic and conventionall egg samples.

\begin{tabular}{ccc}
\hline Egg samples & Positive & Sample \\
\cline { 2 - 3 } & No./30 & $\%$ \\
\hline Organic egg samples & 0 & 0 \\
\hline Conventional egg samples & 3 & 10 \\
\hline
\end{tabular}




\section{DISCUSSION}

Eggs have physical and chemical defenses against bacteria that largely restrict contaminants to the surface of the shell and restrict the growth of those organisms that reach the egg contents. It can be contaminated by a variety of pathogens at any stage of the production chain which cause major risk associated with egg consumption (Chemaly and Salvat 2011) in the form of food borne gastroenteritis in humans throughout the world (Raspoet et al., 2011).

The summarized results in Tables $1 \& 2$ showed that all samples [30] (100\%) of organic egg samples were contaminated with bacteria and total bacterial counts / shell and $\mathrm{ml}$ of albumen and yolk of the examined egg samples ranged from $3.6 \times 10^{2}, 1.5 \times 10^{1}$ and $>10^{1}$ to $2.7 \times 10^{4}, 4.3 \times 10^{2}$ and $4.8 \times 10^{1}$ with average counts of $6.4 \times 10^{3}, 6.6 \times 10^{1}$ and $2.8 \times 10^{1} \mathrm{cfu} / \mathrm{ml}$, respectively.

The highest frequency distribution of the total bacterial counts was $16(53.33 \%), 21(70 \%)$ and $25(83.33 \%)$ lied within the ranges of $10^{3}-, 10^{1}$ - and $10^{1}$ - cfu / shell and $\mathrm{ml}$ of albumen and yolk of organic egg samples, respectively.

These results are agree with those obtained by De Reu et al. (2008), Schwaiger et al. (2008) and Hafez et al. (2013).

The stipulated results in Tables $3 \& 4$ indicated that all samples [30] (100\%) of conventional egg samples were contaminated with bacteria and total bacterial counts / shell and $\mathrm{ml}$ of albumen and yolk of egg samples ranged from $4.7 \times 10^{1}, 1.6 \times 10^{1}$ and $1.1 \times$ $10^{1}$ to $2.2 \times 10^{3}, 2.8 \times 10^{1}$ and $1.9 \times 10^{1}$ with average counts of $7.4 \times 10^{2}, 1.9 \times 10^{1}$ and $1.5 \times 10^{1} \mathrm{cfu} / \mathrm{ml}$ of total bacterial counts, respectively.

The highest frequency distribution of total bacterial counts was $15(50 \%), 30(100 \%)$ and 30(100\%) lied within the ranges of $10^{2}, 10^{1}$ and $10^{1}$ cfu / shell and $\mathrm{ml}$ of albumen and yolk of egg samples, respectively.

These results are similar with those obtained by Hafez et al. (2013), while lower results are recorded by El-kohly et al. (2014).

On the other hand, Table 5 show of that all organic egg samples were free from antibiotics, but only 3 samples $(10 \%)$ of conventional eggs were contained by antibiotics. These results are parallel with those obtained by Hafez et al. (2013). The obtained bacteriological results for both organic and conventional egg samples indicated that there is no significant difference between both organic and conventional eggs. Which clear that nearly similar analytical results of total bacterial counts / examined shell and $\mathrm{ml}$ albumen and yolk of organic and conventional egg samples and only $3(10 \%)$ samples of conventional egg contained antibiotic residues.

One organism that circumvents the eggs defenses by infecting the reproductive tract, (Sparks, 2014) of the infected hen or from fecal matter which contaminate egg shell at time of laying or contaminated during handling egg itself and increased the incidence of disease associated with the consumption of eggs and egg products.

Results of this study indicated that instead of increase demand for organic products due to its healthiness and nutritional value there is no scientific evidence that no additional benefits of organic than conventional eggs that is due to egg production in both system under strict hygienic measures which prevent the contamination of eggs by microorganisms, in addition to take care in use of antibiotics with their withdrawal time which used to minimize the prevalence of bacterial contamination in the laying hen.

\section{CONCLUSION}

All over the world table eggs may be contaminated by many types of microorganisms from infected laying hen or from contamination during any stage of production, so that the producer use broad spectrum antibiotics to control many microorganisms that cause diseases or outbreaks in poultry farms. That antibiotics can be transmitted through table eggs to the consumers causing many development of antibiotic resistant bacteria in human being, so market demand for organic products has expanded rapidly over the past decade. Healthiness and nutritional value are reasons given by some consumers for purchasing organic foods, although there is no scientific evidence that such foods possess additional benefits which conventional food does not possess more importantly, the organic process itself is not a sufficient condition for guarantee the absence of contamination from bacteria and antibiotics.

\section{REFERENCES}

A.P.H.A. (1992): Standard Methods for the Examination of Dairy Products. $16^{\text {th }}$ Ed., American Public Health Association, Washington, D C.

Bahout, A.A. (1991): Influence of shell quality on bacterial infection of commercial hens egg. Thesis Ph.D. of Vet. Med. Science. Zagazig Uni, Egypt.

Chemaly, M. and Salvat, G. (2011): Food borne disease associated with eggs: Microbial hazards and Salmonella enteritidis risk assessment. Improving the Safety and Quality of Eggs and Egg Products, 2: 34-45.

Corry, J.E. (2007): Microbiological analysis of eggs and egg products. Microbiological Analysis of Red Meat, Poultry and Eggs, Pages 183-201. 
DeReu, K.; Messens, W.; Heyndrickx, M.; Rodenburg, T.B.; Uyttendaele, M. and Herman, L. (2008): Bacteriological contamination of table eggs and influence of housing systems. Worlds Poultry Sc., 64: 5-19.

El-Kholy, A.M.; Hassan, G.M. and Dalia, M.A. (2014): Microbiological quality of poultry farm table eggs in Beni-Suef City, Egypt. Assiut Vet. Med. J. Vol. 60 No.124.

FDA (2001): Aearobic plat count. Bacteriological Analytical Manual, $8^{\text {th }}$ Ed., Rev. A.1998. Chapter3Auther: Maturine, and Peer J. T.

Hafez, T.A; EL-Ghayaty, H.A. and Megahed, A.A. (2013): A comparison between organic and conventionally produced eggs. Assiut Vet. Med. J. Vol. 59 No. 136.

Hermansen, J.; Strudsholm, K. and Horsted, $K$. (2004): Integration of organic animal production into land use with special reference to swine and poultry," Livestoc Production Science 90: 11-26.

Maryline K. (2003): Quality of organic animal products. Livestock Production Science 80: 33-40. Unite' Mixte de Recherches Veau Porc (UMRVP), Institute National de la Recherche Agronomique (INRA), Ecole National Supérieure Agronomique de Rennes (ENSAR), 35: 590 Saint-Gilles, France.

Moats, W.A. (1980): Classification of bacteria from commercial egg washers, washed and unashed eggs. J. Appl. Environ. Microbiol. 4: 710-714.

Onozaka, Y.; Bunch, D. and Larson, D. (2006): "What Exactly Are They Paying For? Explaining the Price Premiums for Organic Fresh Produce," Update: Agricultural and Resource Economics. Vol. 9 (6): 1-4.

Raspoet, R.; Gantois, I.; Devloo, R.; Pasmans, F.; Haesebrouck, F.; Ducatelle, $R$. and Van Immerseel, F. (2011): Internal contamination of eggs by Salmonella enteritidis Improving the Safety and Quality of Eggs and Egg Products, 3: 46-61.

Sahin, O.; Morishita, T.Y. and Zhang, Q. (2002): Campylobacter colonization in poultry: Source of infection modes and transmission on anim. Health Res. Rev., 3: 95-105.

Schwaiger, K.; Schmied, E.M. and Bauer, J. (2008): Comparative analysis of antibiotic resistance characteristics of Gram -negative bacteria isolated from laying hens and eggs in conventional and organic keeping quality systems in Bavaria, Germany. Zoonoses Public Health J., 55(7): 331-341.

Shahid, M.A.; Siddique, M.; Reham, S.; Hameed, S. and Hussain, A. (2007): Evaluation of a microbiological growth inhibition assayas a screening test for the presence of antibiotic residues in poultry meat. Amer. J. Food Technol., 2: 457-461.

Sparks, N.H. (2014): Eggs Microbiology of Fresh Eggs. Encyclopedia of Food Microbiology (Second Edition), Pages 610-616.

Speck, M.L. (2009): Compendium of Methods for Microbiological Examination of Food. American Public Health Association, Washington, D.C.

Sylvander, B. (1999): Les tendances de la consummation des products biologiques en Europe: consequences sur les perspectives d'e'volution du secteur (ISARA-Universite' de Laval: Organic agriculture faces it's development; the future issues. Lyon, 6-8 December 1999.

USDA, AMS [U.S. Department of Agriculture, Agricultural Marketing Service](2000): National Organic Program, Final Rule Federal Register 7 CFR Pt 205. December 21.

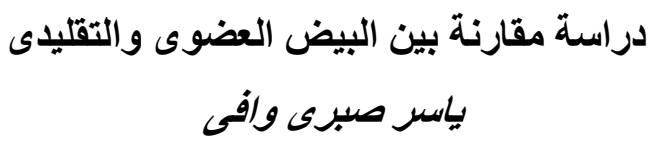

Email: yasserwafy2014@yahoo.com Assiut University web-site: www.aun.edu.eg

تم جمع عدد . . ب عينة عشو ائية من البيض العضوى و التقليدى بواقع • 10 عينة لكل منهما من محلات السوبر ماركت بمدينة اسيوط

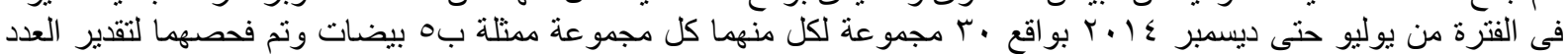

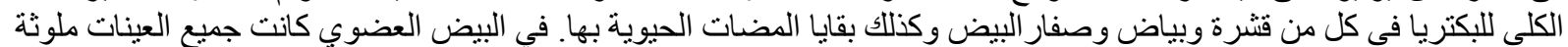

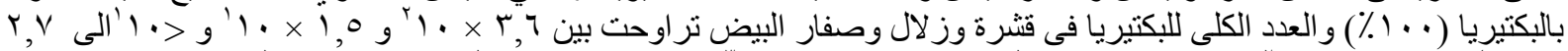

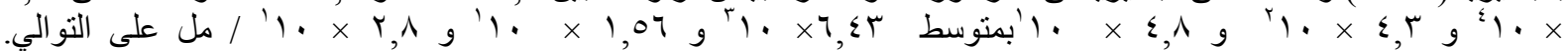

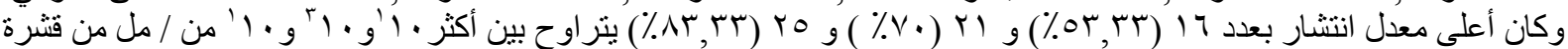

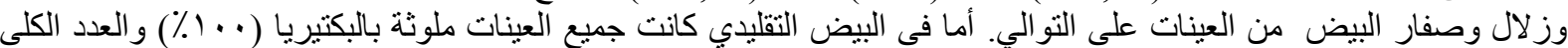

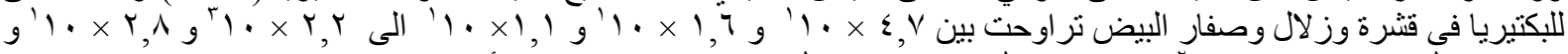

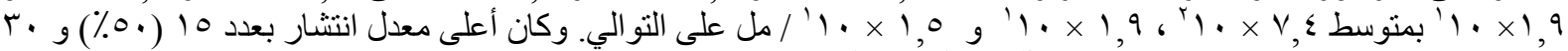

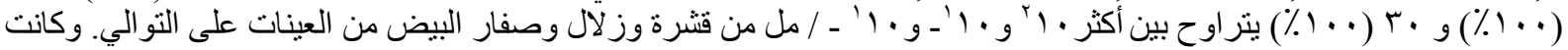

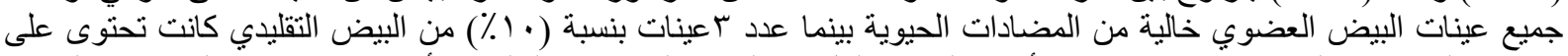

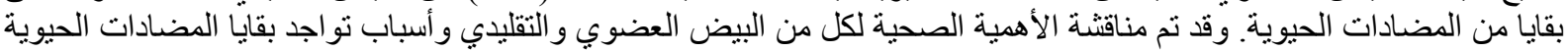
بها وطرق السيطرة عليها. 